\title{
Hegemonia kontzeptua Gramsci eta Laclaurengan: Nafarroako hegemoniaren lehiari hurbilpen bat
}

\author{
The concept of hegemony on Gramsci and Laclau. An \\ approach to the rivalry of the hegemony in Navarre
}

\author{
Eguzkiñe Aiesa Andres • eguzkine.aiesa@gmail.com \\ UNIVERSIDAD DEL PAÍS VASCO/EUSKAL HERRIKO UNIBERTSITATEA \\ UPV/EHU
}

Recibido: 05/04/2016

Aceptado: 07/11/2016

\section{Laburpena}

1979tik 2015era bitarte, UCD, CDN, UPN eta PSNko lehendakaritzak izan ditu Nafarroako Gobernuak. Nortasun espainoleko alderdi guzti hauek ordezkatzen duten sektoreak, UPN buru, «navarrista» bezala definitu izan du bere burua. Bestelako politikagintza defendatzen zuten indar politikoak Nafarroan egondako Gobernu ezberdinetatik kanpo izan dira urte guzti hauetan zehar, salbuespenak salbuespen.

2015eko maiatzaren 24ko hauteskundeek, aitzitik, aurreko hamarkadotan Nafarroan imajina ere egin ezin zitezkeen emaitzak utzi zituzten. Artikulu honen bitartez, Nafarroan 2011-2015eko legegintzaldian hasitako hegemoniaren borrokari begirada bat emateko asmoa dugu. Horretarako, hegemonia kontzeptuak autoreen arabera eta, zenbaitzuetan, autore beren eboluzioaren arabera adiera ezberdinak dituenez, Vladímir Ilich Ulyanov «Lenin», Antonio Gramsci eta Ernesto Laclauk kontzeptuaren inguruan dituzten adierak laburtzen ahalegindu gara, hortik abiatuta Nafarroako kasuari hurbiltzen saiatzeko.

Gako hitzak: Hemegonia, Nafarroa, Gramsci eta Laclaurengan.

\section{Abstract}

Between 1979 and 2015, the Government of Navarre has had presidencies of UCD, CDN, UPN and PSN. All of these parties maintain a Spanish identity, and following the lead of UPN, call themselves "Navarristas.» The political parties that defended a different kind of politics have been out of the government during these years, with some short lived exceptions.

The elections on 24th May 2015, however, had results that would be unimaginable during last decade in Navarre. In this article, we will examine the dispute of hegemony which began during the last political term between 2011 and 2015. To this end, we have tried to explore the various meanings of the concept of hegemony according to academic literature of Vladímir Ilich Ulyanov «Lenin», Antonio Gramsci and Ernesto Laclau and use this in our analysis of the case of Navarre.

Key words: Hegemony, Navarre, Gramsci, Laclau. 


\section{SARRERA}

1979tik 2015era bitarte, UCD, CDN, UPN eta PSNko lehendakaritzak izan ditu Nafarroako Gobernuak. Nortasun espainoleko alderdi guzti hauek ordezkatzen duten sektoreak, UPN buru, «navarrista» bezala definitu izan du bere burua. Bestelako politikagintza defendatzen zuten indar politikoak Nafarroan egondako Gobernu ezberdinetatik kanpo izan dira urte guzti hauetan zehar, salbuespenak salbuespen.

2015eko maiatzaren 24ko hauteskundeek, aitzitik, aurreko hamarkadotan Nafarroan imajina ere egin ezin zitezkeen emaitzak utzi zituzten. Artikulu honen bitartez, Nafarroan 2011-2015eko legegintzaldian hasitako hegemoniaren borrokari begirada bat emateko asmoa dugu. Horretarako, hegemonia kontzeptuak autoreen arabera eta, zenbaitzuetan, autore beren eboluzioaren arabera adiera ezberdinak dituenez, Vladímir Ilich Ulyanov «Lenin», Antonio Gramsci eta Ernesto Laclauk kontzeptuaren inguruan dituzten adierak laburtzen ahalegindu gara, hortik abiatuta Nafarroako kasuari hurbiltzen saiatzeko.

\section{HEGEMONIA GRAMSCI ETA LACLAURENGAN}

Perry Andersonek dioenez, terminoaren erabileraren hastapenak Plejanov eta Axelroden eskutik aurki ditzakegu 1884tik 1917ra bitartean, Errusiako mugimendu sozialdemokrataren baitan (Anderson, 1981: 24). Lehenengoak, bere bilakaera ideologikoaren ostean, Errusiako sozialismoak langileriak absolutismoaren aurka burgesiarekin batera borroka zezan bultzatu behar zuela uste zuen, aldi berean langilegoari bere eta burgesiaren interesen arteko aurkakotasuna ikustaraziz, hurrengo estadioan sozialismoa ezarri ahal izateko (Baron, 1976: 106). 1884ean idatzitako Lanaren Emantzipaziorako Taldearen sorrera programan Errusiako burgesia absolutismoaren kontra ekiteko ahulegia zela eta, ondorioz, langileria antolatuak iraultza demokratiko - burgesaren zuzendaritza hartu behar zuela zioen (Anderson, 1981: 12). Axelrodek, bere aldetik, Piotr Struveri 1901ean bidalitako eskutitz batean honakoa idazten zuen: «Gure proletalgoaren posizio historikoaren arabera, sozialdemokrazia errusiarrak absolutismoaren aurkako borrokaren hegemonia («gegemoniya», esaten zioten) lor dezake» (Anderson, 1981: 12). ${ }^{1}$ Ikusten dugunez, «hegemonia» terminoa «zuzendaritza»ren baliokide bezala erabiltzen zuten autore hauek.

Leninek berak ere modu hartara ulertzen zuen hegemonia, bere idazkietan terminoa aurkitzea ohikoa ez bada ere. Anarkismoak sozialdemokraziari iraultza burgesarekin batera borrokatzean iraultza soziala atzeratu egiten zuela aurpegiratzean, Leninek hau lortu aldera jarrai zitekeen bide bakarrean, errepublika demokratikoaren bidean, alegia, ari zirela erantzunez ezeztatu zuen Dos tácticas de la socialdemocracia lanean (Lenin, 1975: 13). 1905ean, Iraultzaren hasieran, honakoa idatzi zuen: «Proletalgoaren ikuspegitik, gerran hegemonia gainontzekoek baino energia gehiagoz borrokatzen duenari dagokio, etsaia

\footnotetext{
${ }^{1}$ Egilearen itzulpena.
} 
kolpatzeko aukera guztiak probesten dituenari»² (Lenin, 1973: 400). Ikusten dugunez, kontzeptuan elementu berria sartzen du hemen, ekintza iraultzailean izango duen eragina jartzen baitu hegemoniarako baldintza gisa.

Zuzendaritza politikoaz gain, zuzendaritza moral, kultural eta ideologikoa ere barnebiltzen ditu hegemoniak Leninen iritziz, bigarren maila batean bada ere. Hala, langile klaseak nekazariak borrokara eramateko erantzukizuna zuen, modu honetan iraultzaren oinarri soziala handitzen zelako, eta horregatik zioen: "Gure parte hartzeak burgesia iraultzari bizkarra ematera behartuko duela pentsatuz jarduten badugu, iraultzaren hegemonia klase burgesei ematen diogu guztiz» (Lenin, 1975: 80). ${ }^{3}$ Beraz, proletalgoaren eginbeharra kapitalismoaren kontrako borrokan bere klase aliatuak diren gainontzeko esplotatuen zuzendaritza egitea da.

\subsection{Hegemonia Gramscirengan}

\subsubsection{Adiera gramsciarraren bilakaera. Kontzeptua}

Gramscik bere burua Leninen oinordekotzat bazuen ere, hegemonia kontzeptua ulertzeko moduan ezberdintasunak aurki ditzakegu. Ikusi dugu, oro har, honek Leninentzat suposatzen zuena; Gramsciren obrari erreparatuta, hegemonia kontzeptuaren adieran eboluzio bat aurki dezakegu 1926ean Carta al Comité Central del Partido Comunista Soviéticoan terminoa lehenbizikoz erabili zuenetik ondorenera. Hala, bere obraren hastapenetan Leninek ematen zion zentzua (zuzendaritza politikoarena, alegia) ematen zion bitartean, 1929an idazten hasi zen Espetxeko Koadernoetan hegemonia klase eta talde sozial ezberdinen arteko aliantza politiko eta ideologikoen zuzendaritza kultural bezala ikusten zuen (Anderson, 1981: 17). Honela dio Broccolik: «Koadernoetako Gramsciarengan terminoa bi norabideetan ikus daiteke, espetxealdia aurretik kontzeptua zuzendaritza politikoaren zentzuan besterik garatuko ez zatekeen bitartean» (Broccoli, 1977: 88). ${ }^{4}$

Gramsciren idazkietan azaltzen denez, hegemoniak ez du gizarteko egitura ekonomiko eta antolaketa politikoaren gainean bakarrik eragiten, baizik eta, horretaz gain, pentsaeran, joera teorikoetan eta ezagutzeko moduan ere eragiten du (Gruppi, 2011). Leninek bezala, Gramscik ere teoriaren eta ekintzaren artean batasuna egon behar duela dio (Gruppi, 2011), produkzio sistemaren aldaketa egitearekin batera aldaketa intelektual eta morala ere egiteko, hots, irudikari kolektiboa ere aldatzeko.

Elementu hauetatik ondoriozta daitekeenez, etsai bera duten sektore ezberdinak (homogeneoak ez direnak, alegia) artikulatuz frontea («bloke historikoa», Gramsciren terminologian) sortzea eta honen baitan indar ezberdinen arteko kontraesanak elkarbizi daitezen

\footnotetext{
2 Egilearen itzulpena.

${ }^{3}$ Egilearen itzulpena.

${ }^{4}$ Egilearen itzulpena.
} 
INGURUAK [61] | 2016 | 138-152

Hegemonia kontzeptua Gramsci eta Laclaurengan. Nafarroako... | Eguzkiñe Aiesa Andres

borroka ideologikoaren bidez egiten den zuzendaritza prozesu intelektual eta morala litzateke hegemonia.

\subsubsection{Alderdiaren papera hegemoniaren eraikuntzan}

Prozesu honen gauzapenean alderdiak hezitzaile papera jokatu beharra du autore honen ustez, behetik gora eraiki behar baita ordena berria, marxismo klasikoak aldarrikatzen zuen goitik beherako norabidean eraiki beharrean (Rodríguez eta Seco, 2007: 5). Alderdia Maquiaveloren printzearekin alderatuz azaltzen du Gramscik bere ustez hark izan behar duen papera; izan ere, alderdiak gizarte osoaren ikuspegia duenez, etorkizuneko gizartea pentsatzeko eginbeharra du, printzea ere adimen eta moral kolektiboa eraberritzen zuen bateratzailea zen bezala.

Esaten dugunez, hegemoniaren lehia irabazteko, gizartearen gehiengoaren baloreak aldatu beharra dago, gizarte zibilak boterea eskuratu ondoren honen jarraikortasuna bermatuko duen oinarri soziala egon dadin:

«Kultura berri bat sortzea ez da banakako aurkikuntza originalak egitea soilik; horretaz gain, eta bereziki, aurretik aurkitutako egiak zabaltzea da, gizarteratzea, horrela esatearren, bizi-ekintzen oinarri bihurtzea, koordinazio eta ordena intelektual eta moralaren elementu bilakatzea. Gizaki multzo bat egungo errealitatearekiko modu koherente eta bateratuan pentsatzera eramatea, jenio filosofiko batek intelektualen talde txikien jabetza izango den egi berri bat aurkitzea baino ekintza garrantzitsuagoa eta originalagoa da» (Gruppi, 2011). ${ }^{5}$

Honetarako, intelektualek izan beharreko papera argitzen du Gramscik: «Intelektualen maila kuantitatibo eta kualitatiboki garatzen da; baina intelektualen mailaren 'zabaltasun' eta konplexutasun berri bateranzko jauzi oro xinpleen masaren baitako mugimendu analogo bati lotuta dago» ${ }^{6}$ (Gramsci, 1975: 17). Bide honetatik, sistema ideologikoak antolatu eta zabaltzea izan behar du prozesu hegemonikoetan intelektualek bete beharreko papera.

Gramsciren aburuz, langileriaren dikatura plano sozialean lortutako hegemoniaren gauzatze politikoa da; hots, langileen gehiengoa kapitalismoaren eta Estatu burgesaren aurka mobilizatuz gero emango litzatekeena. Beraz, hegemonia gizarte zibilean ematen da, langileriaren diktadura hegemonia horrek jasotzen duen forma izanik.

\subsubsection{Hegemoniaren lehia}

«Risorgimento»ko pasarte batean idatzi zuen: «Talde sozial baten nagusitasuna bi modutan agertzen da, menderatze bezala eta zuzendaritza intelektual eta moral bezala. Talde

\footnotetext{
${ }^{5}$ Egilearen itzulpena.

${ }^{6}$ Egilearen itzulpena.
} 
sozial bat akabatu edota, indar armatuaren bidez menperatu nahi dituen talde aurkarien menderatzailea eta antzeko taldeen eta aliatuen zuzendaria da» ${ }^{7}$ (Gramsci, 2000: 249). Hari honetatik tiraka, Estatuaren zuzendaritza ez duen (eta, beraz, biolentziaren monopolioa ez duen) talde sozial batek gobernu boterea lortu aurretik zuzendaritza lortu beharra $\mathrm{du}$, boterea lortzeko baldintza nagusietarikoa baita. Ondoren, gobernu egituraren boterea eskuratu eta irmoki mantentzean menderatzaile bihurtuko da, baina zuzendari ere izaten jarraitu beharra du, bere posizioan irauteko. Ikus dezakegunez, hegemoniaren ideiarekin batera nagusitasunarena dator hemen. Hala, marxismo ortodoxoaren bloke mugatuak («haiek» eta "gu», hots, proletalgoa eta burgesia) ikusten zituen Gramscik ere, baina honen ustez, bloke historikoa interes eta helburu berak dituzten sektoreen sinbiosia da, bloke kohesionatua, eta ez Leninek zioen aliantza koiuntural soila.

Gramsciren irudikoz, klase hegemonikoak gizarte egiturako klase nagusia izan behar du, gizarte osoaren interesak ordezkatzen dituela sinestarazi edo ikustaraziko duena: "funtsezko taldearen eta mendeko taldeen interesen arteko oreka ezegonkorren etengabeko hobekuntza da estatu bizitza, non nagusi den taldearen interesak puntu bateraino gailentzen baitiren, interes ekonomiko - korporatibo zakarreraino iritsi gabe» ${ }^{8}$ (Gramsci, 1999: 37). Era honetan, klase sozial batek agintea izan dezake menderatze edo inposaketaren bidez, baina ez hegemonia; honetarako, «mendeko klaseen interesak ordezkatu beharra ditu, hala une ekonomiko-korporatiboa kontzientzia politikoaren sorrera bihurtuz» ${ }^{9}$ (Quiroga, 2014: 84).

Arestian aipatzen genuen nagusitasunaren ideiatik tiraka, boterean dagoen sektoreak gainontzekoak menperatzen jarraitzen duenean baina zuzendaritzarako gaitasuna galtzen duenean eta, beraz, gizarte osoaren arazoak konpontzen ez dakielako bere mundua ikusteko era baztertua denean, nagusitasuna krisian sartzen da. Ordura arte menpekoa izan den klase sozial bat zuzendari bihurtuko da gehiengoaren arazoei irtenbide zehatzak planteatzeko gai bada eta atxikimendu berriak jasotzeko gai den gizartea planteatzeko modurik badu, horrela bere inguruan egon daitezkeen sektore sozial ezberdinak batzeko gaitasuna agertuz. Hau da, nagusi den hegemoniari buelta emateko, ordura arte talde hegemoniko izandakoak ezarritako baloreak irauli eta gizartea eredu sozial berri baterantz eraman beharra da (Rodríguez eta Seco, 2007: 3). Izan ere, Gramsciren iritziz, iraultza sozialista baten arrakasta ez datza boterea lortzean, buruzagi burgesak sozialistekin ordezkatzean, produkzio harremanak aldatzean baizik, Rosa Luxemburgek esaten zuen esaldiarekin bat baitzetorren: «Gobernuaren aldekoentzat edo alderdiko kideentzat erreserbatutako askatasuna, hauek asko izanda ere, ez da askatasuna» (Rodríguez eta Seco, 2007: 6). ${ }^{10}$

\footnotetext{
7 Egilearen itzulpena.

${ }^{8}$ Egilearen itzulpena.

${ }^{9}$ Egilearen itzulpena.

${ }^{10}$ Egilearen itzulpena.
} 


\subsection{Hegemonia laclaurengan}

\subsubsection{Subjektua}

Laclauk eta Mouffek, Gramscik ez bezala, hegemoniaren logikan nagusi izango den subjektu bat egon behar denik arbuiatzen dute. Ez dago, haien ustez, aurretik zehaztutako nortasunik ez eta harremanik; aitzitik, artikulazio prozesutik abiatuta azal daitezke subjektuak, hauek egiten den diskurtsoaren arabera era batekoak edo bestekoak izango direlako, definizioaren arabera zentzu bat edo beste hartuko dutelako. Herria da, azken batean, hegemonia prozesu batean eskari baliokideak aldarrikatuko dituen subjektu aktibo (Llacuna, 2008: 300). ${ }^{11}$ Hala, Laclauk eta Mouffek subjektua «subjektuaren posizioa»z, hots, "posizio diskursiboa»z ordezkatzen dute; alegia, egiten den diskurtsoaren arabera soilik gorpuztuko den ideia izango da subjektua.

Beraz, autore hauen ustetan, langile klasea ez da hegemonia prozesuen derrigorrezko protagonista izango (bere zentraltasuna ezeztatzen dute), ez baitago zentro hegemonikorik: instituzio eta mugimendu ezberdinetatik artikulazio praktika hegemonikoak sustatzen dira. Zizekek honakoa dio Laclauri buruz, hau beranduago baieztapenarekin ados agertuko delarik:

«Laclauren aburuz, borroka jakin bat borroka guztien 'baliokide unibertsal' izatera goratzea ez da aurrez zehaztutako zerbait, hegemoniaren aldeko borroka kontingente baten emaitza baizik. Konstelazio zehatz batean, hau langile borroka izan daiteke, beste batean borroka abertzale antikolonialista, beste batean, kultur-tolerantziaren aldeko borroka antiarrazista. Ez dago bere ezaugarri positiboek borroka guztien 'baliokide orokor' rol hegemonikoa izatera aurrez xedatutako borrokarik» (Laclau, 2008: 14). ${ }^{12}$

Sakonean, beraz, ez dago langile klasea gizartearen aldaketa erradikala zuzentzeko subjektu politiko egokiena izatearen inguruko zalantza, subjektuaren ideia bera baztertu daitekeen oztopo bezala irudikatzearena baizik. Herri subjektuaren osaketa, beraz, aurretik ezarritako parametroen araberakoa izan ordez, gizarteko sektore ezberdin eta anitzak artikulatuz egin behar da, beti ere bereizketa dikotomiko baten baitan («haiek» eta "gu»): «Herri subjektua osatzeko aurretiko baldintza barne muga eraikitzea da» (Laclau, 2005: 65). ${ }^{13}$

\subsubsection{Antagonismoa}

Antagonismoa ez da, bi autoreen ustez, ez "aurkakotasuna» ez eta "kontraesana» ere: «Aurkakotasun erreala harreman objektiboa da — hau da, gauzen artean zehazgarria, de-

${ }^{11}$ La razón populista liburuan populismoaren ikuspegitik «herria»ren inguruan eraiki beharreko diskurtsori buruz aritzen da.

${ }^{12}$ Egilearen itzulpena.

${ }^{13}$ LACLAU, Ernesto, La razón populista, Fondo de Cultura Económica, 2005, 65. orr. 
finigarria-; kontraesana ere kontzeptuen artean definigarria den harremana da; antagonismoa objektibotasun ororen muga da» ${ }^{14}$ (Rodríguez, Schietveland eta Terrilles, 2008: 44).

Irudikatzea ezinezkoa den bi terminoren arteko harremana da, beraz, Laclau eta Moufferen ustetan antagonismoa (Retamozo eta Stoessel, 2014:23), zelai diskurtsiboa aurkako bi polotan zatitzen duena (Zubiaga, 2012: 120). "Antagonismoan bestearen presentziak ni neu izan nadin eragozten dit» ${ }^{15}$ (Laclau eta Mouffe, 1987: 145) esaldian, antagonismoak gure nortasuna osoki garatu dezagun eragozten digula adierazten digute bi egileek. Kapitalismoaren egungo fasean nortasun, gune kritiko eta menderaketa modu anitzak daude, herri mugimenduaren lan eremu ezberdinetan ikus dezakegun bezala (ekologistak, feministak, langabeak, gazteria, internazionalismoa...). Honen aurrean, Laclauk askotariko puntu antagonikoak emango direla uste du eta, honen eraginez, edozein herri subjektu aipatu aniztasuna kontutan hartuta eraikitzen hasi beharko dela.

Zizekek Laclau eta Moufferen antagonismoaren kontzeptuari ekarpena egiten dio, hark ez baitu uste loturako termino bakoitzak besteari erabat osatzea eragozten dionik. Ildo honetatik, Zizeken iritziz ez da kanpoko etsaia norberaren nortasuna osotasuneraino garatzea eragozten duena, baizik eta norberak atxiki duen berezko ezintasuna. Gero, ezintasun hori etsaiaren gain proiektatzen dugu. Ulertzeko modu honen arabera, ez litzateke kapitalista izango langileriari bere giza potentziala garatzea eragotziko liokeena; etsai hori kenduta ere, langileriak ezingo bailuke bere nortasun osoa askatu. Laclauk Zizeken ikuspegiak haien «antagonismo sozialen teoria aberastu» ${ }^{16}$ (Laclau eta Mouffe, 1987: 23-24) egiten duela esango du gero.

\subsubsection{Baliokidetasuna eta desberdintasuna}

Baliokidetasunaren logika adibide baten bidez aurkezten dute Laclauk eta Mouffek:

«Kolonizatutako herrialde batean, potentzia menderatzailearen agerpena eduki anitzen bidez azaltzen da egunero: ezberdintasunak janzkeran, hizkuntzan, azaleko kolorean, ohituretan. Eduki hauetako bakoitza, ondorioz, aurrekoen baliokidea da herri kolonizatuarekiko desberdintzearen ikuspuntutik (...). Hau da, baliokidetasunak bigarren zentzua sortzen du, lehenengoaren bizkarroia dena eta, era berean, hau iraultzen duena: ezberdintasunak, hauek guztiek azpian daukaten gauza berdintsua adierazteko erabiliak direnez, ezereztu egiten dira». ${ }^{17}$ (Laclau eta Mouffe, 1987: 147-148).

"Gauza berdintsua» esaten dutenean, argia da zerbait negatiboaz ari direla, kolonizatzailea diskurtsiboki «nortasun negatibo hutsa izatera pasatu» ${ }^{18}$ (Laclau eta Mouffe, 1987: 148) delako. Beraz, elementu ezberdinek gogora ideia bera ekartzen digutenean ematen da baliokidetasunaren logika, autoreak «baliokidetasunek ezberdintasunak ahuldu, baina ez

\footnotetext{
${ }^{14}$ Egilearen itzulpena.

${ }^{15}$ Egilearen itzulpena.

16 Egilearen itzulpena.

17 Egilearen itzulpena.

18 Egilearen itzulpena.
} 
etxekotu, ditzaketela» ${ }^{19}$ (Gold, 2014: 70) esaten badu ere; espazio politikora eramanda, honen sinplifikazioa da: haien artean ezberdinak diren eta desberdintasunaren logikan batak bestearengan eragin gabe elkar bizi daitezkeen eskakizun batzuk antagonista den baten aurrean baliokide bihurtzen direnean emango da baliokidetasunaren logika, alegia, aldarrikapen edo borroka ezberdinek etsai bera dutela edo "helburu goren bera» dutela sentitu eta horren arabera aritzen direnean. Baliokidetasun katea zenbat eta luzeagoa izan, hau da, zenbat eta aldarrikapen ezberdin gehiago egon antagonista baten aurrean, orduan eta beharrezkoagoa izango da denak unibertsalizatuko dituen bat gailentzearen beharra (Laclau, 2000: 302) ${ }^{20}$ Aldarrikapen hauetako bakoitzak, baina, bere berezitasunak ditu, besteengandik bereizita borroka osoa da berez.

Erreakzio gisa, hegemonia prozesuen aurrean ezarritako sistema erantzuten saiatzen da. Espazio politikoaren eraikuntzan desberdintasunaren logika gailentzen denean, eskaera partikularrak ugaritzen dira eta sistema haietako bakoitzari edo batzuei irtenbidea ematen saiatzen da, bai berezitasuna galdu ez dezaten eta, beraz, baliokide bihurtu ez daitezen, edota bai osatutako baliokidetasun katea apurtzeko, antagonismoen papera ezabatzen saiatuz. Gure ustez Laclauk ematen duen adibiderik garbiena Mouffekin batera Hegemonía y Estrategia Socialista liburuan ematen duena da, Bigarren Mundu Gudaren ostean Ongizatearen Estatuaren sorreraren ingurukoa: hau sortuz zihoazen eskakizun ezberdinei erantzuten saiatzen zen, haien artean baliokide bihurtzea ekidinez eta, azken finean, oligarkiaren aurrean Herria herri subjektu bezala eratu zedin eragotziz ${ }^{21}$.

\subsubsection{Hegemonia}

Hegemoniak gizartean tentsio antagonikoak daudela aurresuposatzen du, baina antagonismoa ez da erabatekoa izango, hala balitz, «adierazle flotagarririk» ${ }^{22}$ artikulatzea ezinezkoa litzatekeelako. Diskurtso hegemonikoa adierazle mugikorren jabe egiten da, eta egitura diskurtsibo berri baten puntu nodal ${ }^{23}$ bihurtzen ditu, errealitate sozialari zentzu berria emanez (Rodríguez Marino, Schtieveland eta Terrilles, 2008: 47-48).

\footnotetext{
19 Egilearen itzulpena.

20 Egilearen itzulpena.

${ }^{21}$ Desberdintasunaren logika gizarte kapitalista aurreratuagoetan ematen da, taldeek ez dituztelako argiki bereizi daitezkeen bandoak osatzen, hau da, ez dira talde aurkaritan biltzen (Laclau eta Mouffe, 1987: 152). Hala ere, hauetan ere, eragile batek nolabaiteko baliokidetasunak osatu behar ditu: talde batek ez dena adieraziz soilik lor dezake bere izaera osatzea (Quiroga, 2014: 85).

${ }^{22}$ ADIERAZLE MUGIKORRAK: Kontzeptu bat, edozein posiziotan dagoen edozein pertsonek bere egin dezakeen arte esanahia kenduz joaten zaionean, adierazle huts («significante vacío») bihurtzen da, hau da, esanahi zehatzik ez duen kontzeptua da; adibidez, Euskal Herrian eman diren azken hauteskunde guztietan, boterean dauden alderdiak kenduta denek erabili dute «aldaketa» hitza. Adierazle huts hori edukiz betetzen hasiko dira aktore ezberdinak, terminoari esanahi ezberdina ematen, alegia, irudikari kolektiboan norberak nahi duen zentzua har dezan (hutsik ez dagoen bitartean, hots, esanahi zehatza duen bitartean, ezin baita beste edukiz bete). Adibidearekin jarraituz, alderdi guztiek proposatzen zuten «aldaketa» ez zen berdina, nork bere aldaketa eredua zuen, eta gizartean berea gailentzea zuen helburu. Beraz, adierazle mugikorra baliokidetasun kate ezberdinei lotu dakiekeen kontzeptua da. (Ikus: Montero, 2012: 3).

${ }^{23}$ Laclauk dio diskurtsoaren zentzua aldatzeaz ari bagara, zenbait adierazlek zentzua ematen dutelako dela. Beraz, adierazle hauek diskurtsoaren zentzuaren erreferentzia ematen digute. Puntu nodalek, aldiz, zentzua partzialki ematen dute; ikus: Rodríguez Marino, Schtieveland eta Terrilles, 2008: 42. Eskenatoki politiko batean puntu nodal hegemonikoa (edo hegemonikoak, bat baino gehiago egon daitekeelako) zeintzuk diren ezagutzea ezinbestekoa da.
} 
Antagonista baten aurrean baliokide bihurtzen diren aldarrikapen partikular ezberdinak egon badirelako ematen dira prozesu hegemonikoak. Beste era batera esanda, gizartean dauden eskari ezberdinetako bat aldarrikapen bakarra izatetik gainontzeko aldarrikapen guztiak ere irudikatzera pasatzeari deituko genioke hegemonia.

Laclauren ustetan, artikulazio hegemonikoa eman dadin, bi baldintza bete behar dira: Alde batetik, esan bezala, indar antagonikoak egon behar dira eta, bestetik, indar antagonikoen arteko mugak mugigarriak izan behar dira (Laclau eta Mouffe, 1987: 156-157). Horregatik, Erdi Aroan adibidez, ez zegoen praktika hegemonikorik, boterearen araberako indar antagonikoak egon arren, hauen arteko mugak mugitu ezin zirelako (estamentuak estatikoak ziren, eta ez zegoen honetan diskurtsoaren bidez eragiterik). Aitzitik, «antagonismoa dagoenero ere ezin da praktika hegemonikoa dagoenik esan, (...) elementu mugikorren artikulaziorik ez dagoelako» ${ }^{24}$ (Laclau eta Mouffe, 1987: 231). Beraz, aurkako diskurtsoari artikulatzen ahal zaizkion adierazle mugikorrak egon behar dira praktika hegemonikoa eman ahal izateko.

Autorearen iritziz, hegemonia ez datza gizartearen gainontzekoei nork bere mundu-ikuskera inposatzean, sektore sozial anitzak klase hegemonikoaren diskurtso ideologikora artikulatzean baizik (Laclau, 1969: 10). Prozesu hegemoniko baten emaitza bezala ulertzen du ordena edo egitura, hau da, logika artikulatzaile baten emaitza da prozesu hori (Rodríguez Marino, Schtieveland eta Terrilles, 2008: 36). Horregatik, Laclauren ustetan, ezkerraren gaur egungo erronka herri borroka ezberdinen artean (ekologismoa, feminismoa, antirrazismoa, LGTB...) baliokidetasunak sortuko dituen hegemonia eraikitzea da. Ordea, hegemonia prozesua eta emaitza den arren, ez da inoiz behin betikoa izango (Zubiaga, 2012: 129), diskurtsoen arabera kate ezberdinak eraikitzen ariko baitira beti.

\section{NAFARROAKO HEGEMONIAREN LEHIARI HURBILPEN BAT}

Artikulu honen sarreran esan dugunez, 2015eko maiatzaren 24ean ospaturiko Foru Hauteskundeek ordura arte Nafarroan gauzagarriak izango zirenik pentsaezina zen emaitzak utzi zituzten. Baina, instituzioei begirako ordezkaritza izatetik harago, hegemoniaren gaineko lehia dagoela esan nahi al du honek? Bada, guk baietz uste dugu, bai adiera gramsciarrak ezartzen duen baloreak aldatzearen baldintza ematen ari delako, eta baita 1979tik 2015a arte agintean egondako klaseak jadanik gizarte osoaren interesak ordezkatzen ez dituelako. Hipotesi honetatik abiatuta egin dugu artikulu honetako azterketa.

Gramsciren pentsaeraren ikuspegitik, hegemonia galtzeak agintean dagoen taldeak gizartearen konfiantza galtzea suposatzen du, hegemoniko izatetik menderatzaile izatera pasaz, gizartean kohesioa eragin beharrean honengandik geroz eta urrunago egongo delako. Berak dioenez, bi gertakariren bidez agertzen da hegemoniaren galeraren prozesua: Alde

24 Egilearen itzulpena. 
batetik, zuzendaritzaren porrotagatik edo herritarren sektore handiek konfidantza galdu izanagatik hauek aldarrikapen zorrotzak egitera pasatzen direnean sortzen den krisialdi organikoaren bidez. Bestetik, Estatuko egituren paper errepresiboa indartzera garamatzan alor sozialaren eta politikoaren arteko apurketaren bidez (Rodríguez Prieto eta Seco, 2007: 6).

Nafarroan ematen ari den hegemoniaren lehiari erreparatuta, jarraian azalduko ditugun bi une estruktural bereizi ditzakegu, arestian aipatutako hauteskundeen aurretiko urteak (2011-2015) eta ondorengo hilabeteetako gertakariak hartu ditugularik aztergai:

\subsection{Lehenengo une estrukturala: 2011-2015 legegintzaldia}

Legegintzaldi honetan, Nafarroako Parlamentuan UPN (19 aulki), PSN (9 aulki), PP (4 aulki), EHBildu (7 aulki lortu zituen Bildu koalizioak, baina EH Bilduren sorrera zela eta, 13 izan zituen ia legegintzaldi osoan zehar Nafarroa Baiko kide batzuk koalizioan sartu baitziren), Geroa Bai (Nafarroa Bai formularekin aurkeztuta, 8 aulki lortu zituen, baina EH Bilduren sorrerarekin bost bertara joan ziren, Geroa Bai hirurekin geldituz) eta Izquierda-Ezkerra (3 aulki) zeuden, 2014tik aurrera Podemos eta Ciudadanos jaiotzean hauek ere Nafarroako agertoki politikora jauzi egingo bazuten ere. ${ }^{25}$

2011ko ekainaren 21ean koalizio ituna sinatu zuten UPNk eta PSNk, zeinaren ondorioz UPNko Yolanda Barcina lehendakari izango baitzen 2011ko uztailaren 1etik aurrera, PSNko Roberto Jiménez lehendakariordea izango zen bitartean. Urtea bete gabe zegoela, Jimenezek erkidegoko kontuak publikoki zalantzan jartzearen ondorioz, Barcinak Gobernutik kanporatu zuen Jimenez 2012ko ekainean; PSNk akordioa osoki hautsitzat eman zuen eta, Gobernuan zeuden Anai Astiz eta Elena Torres PSNko kideek dimitituz, gobernu akordioa behin betiko hautsi zen, PSN oposiziora pasaz. Hala, UPN gutxiengoan gelditu zen legebiltzarreko akordioen bidez agintzeko nahiarekin, baina gai garrantzitsutan, aurrekontuetan kasu, ezin izan zuen akordiorik lortu. PSNk Barcina jotzen zuen akordioetarako ezintasunaren iturburu (Diario de Noticias, 2013/03/18). Ordea, UPNk 2013ko martxoan ospatutako bere IX. Kongresuan, 871 bozka (\%51) lortu zituen Barcina berretsi zuen alderdiaren lehendakaritzan, PSNrekin harremana berreskuratu nahi zuen Alberto Catalán aurkariari 76 bozkagatik irabazi eta gero. Hau UPN barnean zeuden botere-borroken adierazle bat gehiago baino ez zen izan.

Nafarroako Gobernuaren blokeo eta paralisi egoera honetan, ustelkeria kasuak ugaltzen zihoazen (Cervera kasua, eta abar) ${ }^{26}$, CAN auziarekin sabaia jo arte. Honetaz gain, krisialdiak gogor jotzean egindako murrizketek Nafar Gobernuak izandako handitasunarekin egiten zuen talka, UPNren bozkaleen artean ere Los Arcoseko zirkuitua edo Iberdrolako

${ }^{25}$ 2015eko maiatzaren 24ko hauteskundeetan parlamentuan ordezkaritza lortu zuten alderdiak aipatu ditugu soililk; Ciudadanosek ez zuen ordezkaritzarik lortu, baina aurrerago ikusiko dugunez, aurkeztu izan hutsak eragin handia izan zuen hauteskunde emaitzei dagokienean.

${ }^{26}$ Kontuz! eragileak egindako lana aipagarria da. Ikus: www.kontuz.org 
akzioen erosketa bezalako ekintzak zalantzan jartzen zirelarik (navarraconfidencial.com, 2014/08/25). Gramscik aipatzen zuen «interes ekonomiko-korporatibo zakarreraino» iritsia zen nafar elitea nafar jendartearen ikuspegitik, UPN buru zen nafarzaletasun klasikoaren nagusitasuna kolokan jarriz. Ustelkeriaren aurkako mobilizazioekin hasita, paisaia soziopolitikoa aldarrikapen ezberdinek gurutzatua izaten hasi zen: euskalgintzarenak, sindikalgintzarenak, feminismoarenak (bereziki abortoaren legearen aurka egindako kanpainak dira aipagarriak), memoria historikoarenak, egitura handien aurkakoak... Aldarrikapen guztiak baliokidetasun katean biltzen hasi ziren, «UPN kanpora» eta "ique decida el pueblo!» lemen pean hauteskundeak aurreratzeko eskatuz. Ordura arte baztertuak izan ohi ziren eta hazkundean zeuden sektore sozialen behar politikoek, instituzioetako indar korrelazioa aldatzeko itxaropena zabaldu zuten gizartean.

Alta, hurrengo foru hauteskundeek jendartean ilusioa eta itxaropena sortu bazuten, alderdi politikoen ikuspegitik ere klabetzat ematen ziren hauek, ordurako bi gizarte eredu kontrajarri defendatzen zituzten bi bloke politikoren arteko lehia bailitzan. Horrela, alor honetan ere, proiektu politikoen arteko konfrontazioa aurrera joan ahala, bi baliokidetasun kate osatzen joan ziren: Alde batetik, UPN, PSN, PP eta Ciudadanos (parlamentutik kanpo), estatus quoa mantentzearen alde zeudenak eta aldaketa politiko eta soziala aldarrikatzen zuten EH Bildu, Geroa Bai, Izquierda-Ezkerra eta oraindik ere legebiltzarretan ez zegoen Podemos, bestetik.

Alor politikoko kateak oraindik ere osatze prozesuan zeudenean, ordea, zenbait alderdik bere burua non kokatzen zuten ez zegoen hain argi; Laclauren terminologian, «flotagarri» zeudela esango genuke. PSNren kasuan, 2015eko Foru Hauteskundeak eta gero arte iraungo zuen zehaztasun ezak. Izan ere, 2013ko martxoan EH Bilduk (Bilduk eta Aralar-Na Bai taldeek) «arduragatik», "hauteskundeen aurreratzea behartzeko»" (Diario de Navarra, 2013/03/22) Barcinaren aurkako zentsura mozioa aurkeztuko zuela iragarri zuen, Nafar Parlamentuko aritmetikaren arabera hau aurrera joan zedin PSNren aldeko bozka behar zelarik. Prentsaurreko hartan beste edozein talderekin «zentsura mozioaren forma eta hautagaiak kontsentuz hautatzeko irekia» agertu zen arren, 2013ko apirilaren 5ean koalizioak bakarrik aurkeztu zuen azkenean. 2013ko apirilaren 18an PSNko Jimenezek bere alderdia abstenitu eta Barcinaren dimisioa eskatuko zuela iragarri zuen (Diario Vasco, 2013/04/18). EH Bildu, Geroa Bai eta Izquierda-Ezkerraren aldeko bozkak izan bazituen ere, zentsura mozio hura ez zen aurrera atera, baina kate politikoa artikulatzen hasia zen ordurako. Maila zibilean ere hondarra utzi zuen PSNren jarrerak, PSN-rekiko mesfidantza areagotuz.

Hala, irudikari kolektiboan etsaia nor zen argi izanda, bi kate hauek aurrez aurre ipinitako bi jarrera izate aldera zihoazen, polarizazio egoerara iritsiko zela emanez. Honela

\footnotetext{
27 Egun batzuk lehenago, 2014ko martxoaren 13an, alegia, Nafar Parlamentuak Barcinaren dimisioa eskatu ondoren ez zen mugimendurik ez egon. Ondorioz, zentsura mozioa zen hauteskundeak aurreratzeko parlamentuaren esku zegoen tresna bakarra, hauteskundeen deitzea eta konfiantza-arazoa lehendakaritzaren esku baitaude.
} 
definitzen du Zubiagak polarizazioa: «Polarizazioa muturreko aktore sozialak are gehiago urruntzen dituen prozesua da, beren alorrera ordura arte erdiko posizioetan, posizio epeletan, zeuden beste aktoreak ekarriz». ${ }^{28}$ (Zubiaga, 2012: 127).

Hamar hilabete beranduago, Ogasuneko zuzendari-kudeatzaile ohiak Goicoechea kontseilariari zenbait zergadunekiko mesede-tratua izatea leporatzean sortutako zalapartaren eraginez (2014/02/12), 2014ko otsailaren 13an PSN Barcinaren aurkako zentsura mozio berria aurkezteko prest agertu zen prentsaren aurrean, hauteskunderik egonak ez zirenez EH Bilduren aldeko bozka beharko bazuen ere (Zoom News, 2014/02/13). Handik ordu gutxira, Elena Valenciano PSOEko buruzagiak «PSOE Bildurekin iskinara ere ez doala» ${ }^{29}$ esan zuen Madrildik (El Mundo, 2014/02/13), Jimenezek «PSOE Nafarroan bera zela» erantzunez (La Gaceta, 2014/02/13). Kalean mobilizaziorik falta izan ez ziren 21 egunen buruan, martxoaren 6an PSN zentsura mozioaren aurkako jarrerarekin atera zen bere herrialdeko batzarretik, herriaren irudikarian aldaketatik urrunduz, eta «UPN kanpora» leloa «UPN-PSN kanpora» leloagatik aldatuz.

Muturretan zeuden UPN eta EH Bilduk, krisket mekanismoa erabili zuten hauteskunde kanpainan zehar, honek moderatuekiko presioa areagotuz.

\subsection{Bigarren une estrukturala: 2015-2019 legegintzaldia}

Hala ere, lehenago edo beranduago emango ziren hauteskunde batzuen emaitzek PSN-rik gabeko aldaketarako aukerarik emango zutenik zalantzan jartzen zen alderdi gehienen artean. Hortaz, 2015eko maiatzaren 24ko hauteskundeetan Geroa Bai, EH Bildu, Podemos eta Izquierda-Ezkerraren artean 26 parlamentari eskuratuak zirela ikusita ere, ${ }^{30}$ PSN oraindik ere aldaketaren kate-mailatzat zuten EH Bildu kenduta gainontzeko alderdi guztiek, geroko negoziaketek erakutsi zutenez (eitb.eus, 2015/05/27; Noticas de Álava, 2015/05/29). ${ }^{31}$ Are gehiago, PSNk eta Geroa Baik 2015eko maiatzaren 29an ospaturiko bileraren ostean, PSN EH Bildurik gabeko Geroa Bairen gobernu baten aldeko bozka emateko prest agertu zen eta Uxue Barkosek (Geroa Baiko buruak) PSNrekin «elkargune motaren batera iristeko» borondatea azaldu zuen, EH Bildu kanpo kokatzen ez bazuen ere (Diario Vasco, 2015/05/29).

Ia bi hilabeteko negoziaketen fruitu, 2015eko uztailaren 17an Geroa Baik, EH Bilduk, Podemosek eta Izquierda-Ezkerrak Uxue Barkos buru izango zuen Aldaketaren Gobernuaren iparrorratza izan beharko zuen akordio programatikoa lortu zuten, uztailaren 20an Nafa-

\footnotetext{
${ }^{28}$ Egilearen itzulpena.

${ }^{29}$ Egilearen itzulpena.

${ }^{30}$ UPNk 15 aulki lortu zituen, GBk 9, EH Bilduk 8, Podemosek 7, PSNk 7, PPk 2 eta IEk 2.

Kontutan hartu beharrekoa dugu hemen, egun «aldaketaren indarrak» deituak diren laurek 26 parlamentari lortu bazituzten, Ciudadanos foru hauteskundeetan aurkeztu izanagatik ere izan zela, modu batean. Izan ere, indar honek eskuratutako ia 10.000 bozkak UPN, PP edo PSNra joan izan balira, kontrako katearen alde geldituko zatekeen emaitza.

${ }^{31}$ Podemosek gaiaz hitz egitea ekiditen zuen garai hartan.
} 
rroako Legebiltzarrean lehenbiziko saiakeran gehiengo osoz onartuz (Noticias de Navarra, 2015/07/17).

\section{ONDORIOAK}

Perry Andersonek Gramsciren Antonimietan aipatzen du: "Gaur egun klasikoa den erregimen parlamentarioan, hegemoniaren jardute arrunta indarra eta onarpenaren arteko konbinazioak ezaugarritzen du; hauek, oreka aldakorra osatzen dute, indarrak onarpenaren gainetik gehiegi gailendu ere gabe» ${ }^{32}$ (Anderson, 1981: 18). Honen bidetik, artikulu honen 2.1.3. puntuan esaten genuen bezala, Gramsciren ustez hegemonia etsaiaren menderatze bezala edota zuzendaritza intelektual eta moral moduan azal daiteke. Baina, aitzitik, honakoa esaten digu Helena Béjarrek: «Gizartea norabide jakin batean eramateko saiakerak mugimendu bati, aldaketa bati, ematen dio bide, baina nahi den norantzaren aurkakoan. Sendagaiek kontraindikazioak dituzten bezala, aldaketa sozialak ere ondorio doilorrak eragiten ditu, aldaketa politikoak hasierako xedea okertzen du eta, aktore sozialei, 'kukuak oker jotzen die'»33 (Béjar, 2008: 64).

Aipu hauen ondorioz, eta Gramscirengandik hegemonia irabazteak gizarteko baloreen aldaketa ere suposatu behar izatearen ideia hartuta, gure ustez, Nafarroako Aldaketaren Gobernuak Erregimena (UPN-PSN-PP sektorea) menderatzearen bidez garaitu nahi izatea tamainako akats politikoa litzateke, hegemonia ez baitago oraindik ere irabazia, irabazte bidean baizik. Izan ere, aipatzen genuen bezala, bi baliokidetasun kate osatuak daude oraindik ere egun (aldaketaren aldekoa bat, aurkakoa bestea), sektore batzuk oraindik ere mugikor aurkituz.

Zubiagak dio «berrikuntzak, ustekabekoaren agerpenak, berritzailea izanagatik, politikak ezarri nahi digun konpartimentazioa apurtzen du. Horrek ez du esan nahi benetan berria denik, baina ematen ${ }^{34}$ duela (Zubiaga, 2012: 128). Zentzu honetan, Nafarroako klase politikoa, botere faktikoak zein gizarte zibila, egoera berriari moldatu nahian ari dira, aldaketak suposa dezakeena barneratu eta nork bere hurrengo urratsak definitu nahirik. Erregimena Aldaketaren baliokidetasun katea apurtzen saiatu eta bere baliokidetasun katea luzatzen saiatuko dela aurreikusi badaiteke ere, oraindik ere nolabaiteko noraeza ikusten zaion honetan, aldaketarekiko erresistentzia artikulatzen hasia dela adierazten diguten zenbait zantzu ikus ditzakegu, hezkuntza OPEak, Iruñeko desfilearen Baltasar erregearen afera, edo Polizia Nazionalaren esposaketaren debekuaren aurreko oldarraldia, kasu.

Honen aurrean, Nafar Gobernuak eta aldaketaren aldeko indarrek mendeko sektore ezberdinak eta anitzak interpelatu (gizartearen gehiengoarekin konaktatu, «obedituz

\footnotetext{
32 Egilearen itzulpena.

${ }^{33}$ Egilearen itzulpena.

34 Egilearen itzulpena.
} 
agindu») eta ahalduntzeko (instituzioen demokratizazioa ekarriko luketen parte hartzeko mekanismoak ezarri eta sustatzeaz gain, herri mugimenduak berak modu autonomoan lan egitea ahalbidetu) gaitasuna agertu beharko lukete. Ildo honetatik, Nafarroako Gobernuak inklusioa bermatu beharko luke, gizartea zatitzen duten eta maiatza arte bizi ziren bazterketa sozialen aurrean ezberdintasunak murriztuz eta gizartearen eskubideen unibertsaltasuna zailtzen edota eragozten duten interes partikularren zein Nafarroaz gaindiko instituzioen aurrean autogobernuaren defentsan tinko agertuz. Izan ere, aldaketa politikoak aldaketa soziala bultzatuko ez balu, edo gizarteak hala hautemango ez balu, oraindik ere hegemoniko bihurtu ez den aldaketak hurrengo Foru hauteskundeak gal litzake, honela botere faktikoaren laguntza dutenak beste hamarkada batzuetarako hegemoniko bihurtuz.

\section{REFERENCIAS BIBILOGRÁFICAS}

Anderson, P. (1981). Las antinomias de Antonio Gramsci. Barcelona: Fontamara.

Baron, S. H. (1976). Plejanov. El padre del marxismo ruso. México: Siglo Veintiuno Editores.

Béjar, H. (2008). La dejación de España. Madrid: Katz.

Broccoli, A. (1977). Antonio Gramsci y la educación como hegemonía. México: Nueva Imagen.

Gold, T. (2014). Democracia, hegemonía y populismo. Ernesto Laclau lector de Claude Lefort. Las Torres de Lucca: revista internacional de filosofía política. 3 zbk., 57-76. or.

Gramsci, A. (1975). El materialismo histórico y la filosofía de Benedetto Croce. México: Juan Pablos Editor.

Gramsci, A. (1999). Cuadernos de la Cárcel, V. alea. México: Ediciones Era.

Gramsci, A. (2000). Il Risorgimento. México: Juan Pablos Editor.

Gruppi, L. (2011). El concepto de hegemonía en Gramsci. Eskuragarri: http://culturas-culturas-culturas.blogspot.com.es/2011/04/el-concepto-de-hegemonia.html

Laclau, E. (1969). Hitzaurrea, in: Anderson, P. La cultura represiva. Elementos de la cultura nacional británica (5-21. or.). Barcelona: Anagrama.

Laclau, E. (2000). Construyendo la universalidad. In: Butler, J., Laclau, E. eta Zizek, S., Contingencia, hegemonía, universalidad. Diálogos contemporáneos en la izquierda (281306 or). Buenos Aires: Fondo de Cultura Económica. 
Laclau, E. (2005). La razón populista. Buenos Aires: Fondo de Cultura Económica.

Laclau, E. (2008). Debates y combates. Por un nuevo horizonte de la política. Buenos Aires: Fondo de Cultura Económica.

Laclau, E. eta Mouffe, Ch. (1987). Hegemonía y estrategia socialista. Hacia una radicalización de la democracia. Madrid: Siglo veintiuno Editores.

Lenin, V.I. (1973). Obras escogidas en doce tomos, II. alea. Moscú: Progreso.

Lenin, V.I. (1975). Obras escogidas en doce tomos, III. alea, Moscú: Progreso.

Llacuna, E. (2008). Laclau, Ernesto. La razón populista. Boletín Americanista, 58 zbk., 299300. or.

Montero, A.S. (2012). Significados vacíos y disputas por el sentido del discurso político: un enfoque argumentativo, Identidades, 3 zbk., 1-25 or.

Retamozo, M. eta Stoessel, S. (2014). El concepto de antagonismo en la teoría política contemporánea. Estudios Políticos, 44 zbk., 13-34. or.

Rodríguez Marino, P., Schtieveland, E. eta Terrilles, R. (2008). Ideología, discurso, subjetividad. La reconfiguración de la problemática de la hegemonía en la obra de Ernesto Laclau. Revista de Filosofía y Teoría Política, 39 zbk., 31-51. or.

Rodríguez Prieto, R. eta Seco Martínez, J.M. (2007). Hegemonía y Democracia en el siglo xxi: ¿Por qué Gramsci?. Cuadernos electrónicos de filosofía del derecho, 15 zbk., 1-14. or.

Quiroga, M.V. (2014). Discursos y sujetos. Algunos nexos y tensiones entre las perspectivas teóricas de Michel Foucault y Ernesto Laclau. Estudios Politicos, 45 zbk., 70-94. or.

Zubiaga, M. (2012). Poder como hegemonía: contingencia y articulación, in: Ahedo, I. eta Grostidi, I. (ed.), Política Integral (112-130. or.). Pamplona: Pamiela. 